\title{
A New Record for the Flora of Turkey: Cerastium szowitsii Boiss. (Caryophyllaceae)
}

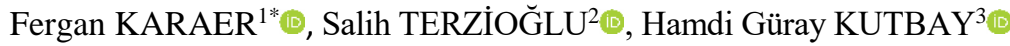 \\ ${ }^{1}$ Ondokuz Mayıs University, Faculty of Education, 55000, Samsun, TURKEY \\ ${ }^{2}$ Karadeniz Technical University, Faculty of Forestry, 61080, Trabzon, TURKEY \\ ${ }^{3}$ Ondokuz Mayıs University, Faculty of Science-Literature, 55000, Samsun, TURKEY \\ *Corresponding Author: sterzi@ktu.edu.tr
}

Received Date: 24.12.2019

Accepted Date: 11.02 .2020

\begin{abstract}
Aim of study: In this study, it was aimed to contribute the vascular plant species diversity of Turkey.

Area of study: A8 Artvin: Hatila Valley National Park, rocky places, roadsides, $559 \mathrm{~m}$ in NE Anatolia.

Material and method: Plant materials were collected during the field studies in the years 2011 and

2012. They were processed according to standard herbarium techniques and stored at three herbariums.

Main results: Cerastium szowitsii Boiss. is reported as a new species to the Turkish flora.

Research highlights: Recent studies on vascular flora underlined that native and non-native taxa have been newly recorded from Turkey. Thus, this kind of studies should be conducted in mountainous part of NE Anatolia.
\end{abstract}

Keywords: Anatolia, Artvin, Caryophyllaceae, Cerastium, New Record.

\section{Türkiye Florası İçin Yeni Bir Kayıt: Cerastium szowitsii Boiss. (Caryophyllaceae)}

\section{$\ddot{O} \mathbf{z}$}

Çalışmanın amacı: $\mathrm{Bu}$ çalışmada, Türkiye'nin vasküler bitki türlerinin çeşitliliğine katkıda bulunulması amaçlanmış̧ır.

Çalıșma alanı: A8 Artvin: Hatila Vadisi Milli Parkı, kayalık alanlar, yol kenarı, Kuzeydoğu Anadolu'da $559 \mathrm{~m}$.

Materyal ve yöntem: 2011 ve 2012 yıllarında yapılan arazi çalışmaları sırasında toplanan çok sayıda bitki materyalleri standart herbaryum tekniklerine göre hazırlanmış ve üç ayrı herbaryuma yerleştirilmiştir.

Temel sonuçlar: Cerastium szowitsii Boiss. Türkiye florası için yeni bir tür olarak rapor edilmektedir.

Araştırma vurgularl: Damarlı bitkiler üzerine yapılan son çalışmalar, Türkiye'de doğal ve egzotik yeni bitki kayıtlarının yapıldığını ortaya koymaktadır. Bundan dolayı bu tür çalışmaların Kuzeydoğu Anadolu'nun dağlık kesimlerinde yapılmalıdır.

Anahtar kelimeler: Anadolu, Artvin, Caryophyllaceae, Cerastium, Yeni Kayit.

\section{Introduction}

The family Caryophyllaceae Juss. includes 89 genera and about 3000 species worldwide (Rabeler \& Hartman, 2005). The family has been divided into three subfamilies such as Caryophylloideae, Paronychioideae and Alsinoideae to which the genus Cerastium L. belongs (Bittrich, 1993; Poursakhi et al., 2013). This genus has more than 100 taxa throughout the world and distributed in Europe, Eurasia, Africa and America (IPNI, 2019; Miceli et al., 1997; Scheen et al., 2004).
Although many studies have been conducted on the vascular flora of Karadeniz Region of Turkey, some native and naturalized vascular plant taxa have hitherto been recorded from the region (e.g. Karaer \& Terzioğlu, 2014; Terzioğlu \& Karaer, 2014). Ecologically tolerated taxa can be easily arrived at different sites beyond their previous geographical ranges which makes them worthy of attention (Terzioğlu \& Anşin, 2001). As well, some vascular native plant taxa have been recorded to Turkish Flora with intensive floristic studies. 
The genus Cerastium was firstly revised by Cullen (1967) in Flora of Turkey where he recognised 29 taxa. Adding two new ones, the number of taxa increased to 39 in Turkey (Ayaşlıgil, 1984; Davis \& Mill., 1988). Recently, 37 species have been reported from Turkey (Keskin, 2012; Keskin, 2018). In May 2011 and 2012, some Cerastium specimens were collected from Hatila Valley National Park (NE Anatolia - Artvin) by the authors during the project on "Long-term Development Plan of Hatila Valley National Park". There are no previous reports of this species in Turkey.

The aim of the present study is to make contributions to the vascular flora of Turkey by recording Cerastium szowitsii Boiss. (Szowitz's Chickweed).

\section{Materials and Methods}

The plant specimens for this study were collected from A8 Artvin province during fieldworks in 2011-2012. They were checked in national (KATO, OMUB, ANK, GAZI, HUB, ISTE, ISTF) and international ( $\mathrm{G}, \mathrm{K}, \mathrm{B}$ and $\mathrm{E})$ herbariums. After checking the literature, we concluded that the specimens of $C$. szowitsii were previously unknown in Turkey (Cullen, 1967; Keskin, 2012; Keskin, 2018). Additionally, all specimens were cross-checked according to the relevant literature (Boissier, 1867;
Karyagin, 1950-1961; Móschl, 1966; Komarov, 1970; Tolmachev, 1970; Sell \& Whitehead, 1993; Takhtajan, 1954-2001; Güner et al., 2000).

The specimens of new finding were kept at the OMUB (in Ondokuz Mayıs University), KATO and KTUB (both in Karadeniz Technical University) Herbariums.

\section{Results and Discussion}

Cerastium szowitsii Boiss., Fl. Or. I (1867) 717; Voron. In Fom. and Voron. Opred. rast. Kavk. il, 2, 162. (Figures 1, 2).

Syn. Cerastium gnaphalodes Fenzl. subsp. album Buschm, Cerastium szowitsii var. album (Buschm.) I.V. Sokolova ex Czerep. (Sokolova, 1996).

Perennial plant with reduced sterile shoots, stem erect, white-tomentose, except in lower part, (-5)10-20 cm. Leaves lanceolate to linear-lanceolate, $10-25 \mathrm{~mm} \mathrm{x}$ 2-3.5 (-5) mm, acute. Flowers 1-4 at the end of the stem, pedicels erect, longer than calyx. Bracts acute, broadly scarious -margined. Sepals lanceolate with scarious margins 7-8 $\mathrm{mm}$, petals white twice as long as calyx lobed to one -third. Styles 5; capsule opening by 10 teeth, capsule teeth straight or slightly spreading, capsule oblong, about twice as long as calyx, dehiscing by erect, revolutemargined teeth. Seeds ca. $1 \mathrm{~mm}$ long, bluntly tuberculate. Flowering time 6-8.

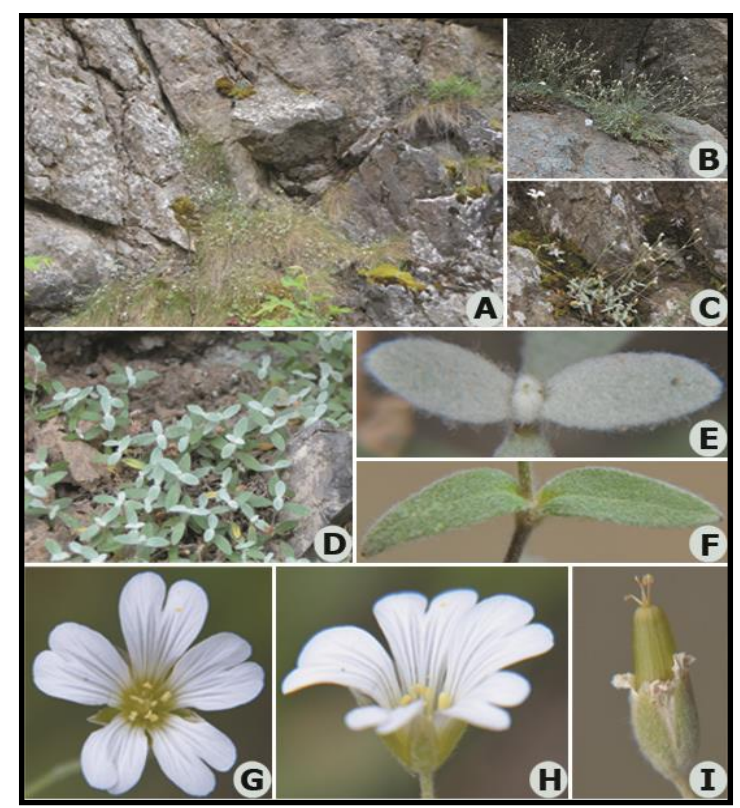

Figure 1. Cerastium szowitsii A, B, C- Habitats; D, E- Reduced sterile shoots; F- Cauline leaves of fertile shoot; G, H- Flowers; I- Fruit 
Voucher specimens: A8 Artvin - Hatila Valley National Park, rocky places, roadsides, 559 m, 19.v.2012, KATO 18913!
KTUB 1097! ibid., FK 17305 (OMUB!), FK 18250 ibid., 23.v.2011 (OMUB!) (Figure 2).

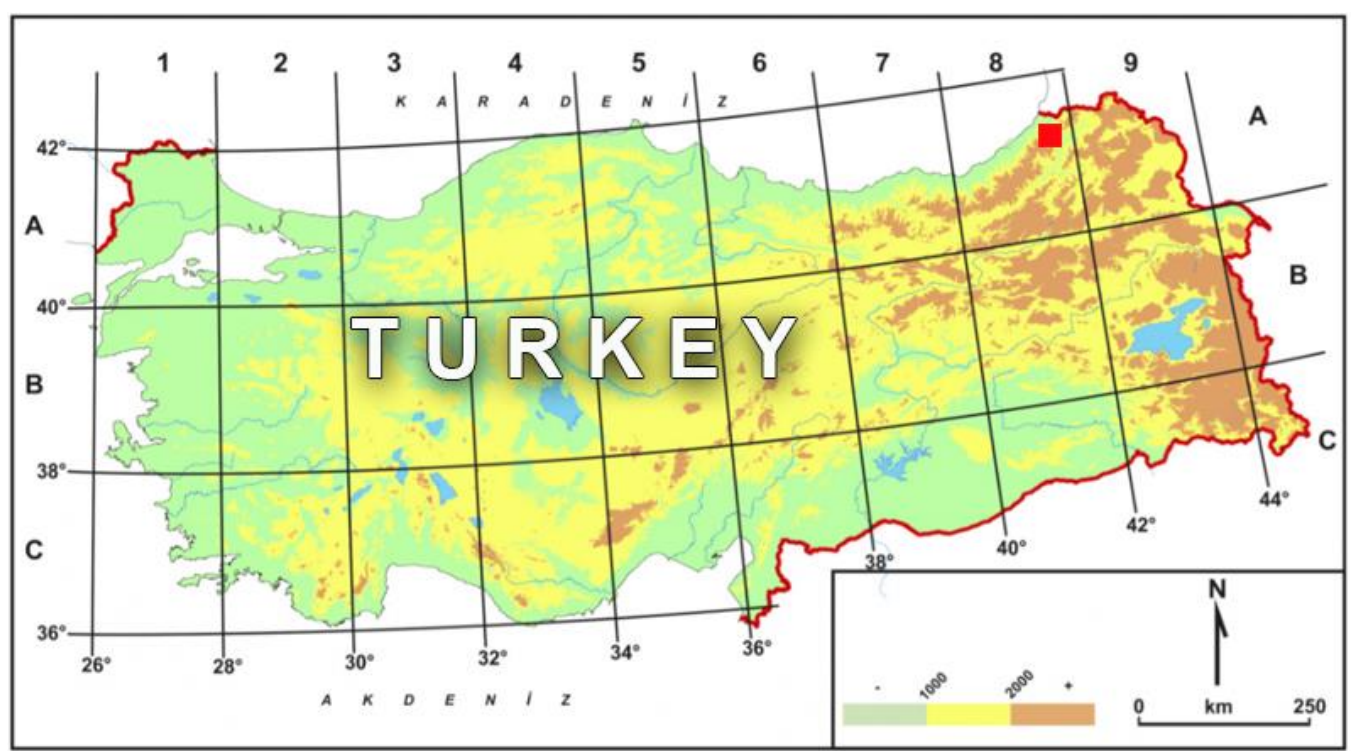

Figure 2. Distribution of Cerastium szowitsi ( ) in Turkey (Adapted from Güner \& Ekim, 2014)

Alpine and subalpine rocks, at altitudes of 2000-3300 $\mathrm{m}$ in Caucasus (E. and S. Transc.), Armenia (Type: Armenia Rossica, mont Kias in G).

C. szowitsii is close to $C$. banaticum by having mostly with sterile shoots in their axils and two of them are located in the section Cerastium. Differently, C. banaticum have retrorsely scabrid-pilose stems; linear to very narrowly lanceolate, pilose or rarely glabrous leaves; ovate-lanceolate, 5-6 mm sepals; 7-11 mm petals. Moreover, the leaves of C. szowitsii are lanceolate to linearlanceolate, white-tomentose; sepals lanceolate, 7-8 mm; petals $14-16 \mathrm{~mm}$; stem erect, white-tomentose except in lower part. C. szowitsii is perennial plant with reduced sterile shoots, stem erect, white-tomentose that closely resembles $C$. gnaphalodes but is easily distinguished by the bracts completely herbaceous and leaves \pm linear, mostly with sterile shoots in their axils.

In Turkey (Artvin), C. szowitsii grows at altitude of 500-600 $\mathrm{m}$ on volcanic rocky slopes, in cracks and ledges on near-vertical cliffs of the Hatila Valley National Park. It apparently favours environmentally harsh, sparsely degraded forests. The soil is likely well drained. Degraded forest vegetation is especially widespread in the upper part of the valley and includes species of the QuercoFagea super class from plant sociological point of view, with the shrubs such as Crataegus microphylla, C. monogyna, Acer campestre subsp. campestre, Buxus sempervirens, Quercus macranthera subsp. syspirensis, $Q$. pubescens and Carpinus orientalis.

It is a hemicryptophyte species and the most important associated species of which are (taxa endemic to Turkey in boldface) Erysimum thyrsoideum subsp. ponticum, Moehringia trinervia, Saxifraga paniculata, Phedimus spurius, Sedum obtusifolium, S. hispanicum var. hispanicum, S. album, Cistus creticus, Sempervivum glabrifolium, Thesium billardieri, Linaria coriifolia, Verbascum natolicum, Clinopodium vulgare, Scutellaria salviifolia and Lapsana communis.

\section{Acknowledgements}

We are indebted to the directors of the following herbariums; E, OMUB, KATO, GAZI, ANK, HUB, ISTE and ISTF. The authors want to express their special thanks to General Directorate of Nature 
Conservation and National Parks, and ODOPEM for their financial supports.

\section{References}

Ayaşlıgil, Y. (1984). New taxa and records from S.W. Turkey. Notes R.B.G. Edinburgh, 42, 69-76.

Bittrich, V. (1993). Caryophyllaceae. K. Kubitzki et al. (eds.) The families and genera of vascular plants. Berlin: Springer-Verlag, 2, 206- 236.

Boissier, E. (1867). Cerastium L. Boissier, E., (Ed.), Flora Orientalis. Basel: apud $\mathrm{H}$. Georg., 1, 712-730.

Cullen, J. (1967). Cerastium L. Davis, P.H., (Ed.), Flora of Turkey and the East Aegean Islands. Edinburgh: Edinburgh University Press, 2, 73-85.

Davis, P.H.\& Mill, R (1988). Cerastium L. Davis, P.H., (Ed.), Flora of Turkey and the East Aegean Islands, Edinburgh: Edinburgh University Press, 10., 69-71.

Güner, A. \& Ekim, T. (Edit.). (2014). Resimli Türkiye Florasl, cilt 1. İstanbul: NGBB Yayınları Flora Dizisi 2, Flora Araştırmaları Derneği ve Türkiye İş Bankası Kültür Yayınları.

Güner, A., Özhatay, N., Ekim, T. \& Başer, K.H.C. (2000). Flora of Turkey and the East Aegean Islands, Edinburgh: Edinburgh University Press, 11.

IPNI. (2019). http://www.ipni.org/, Accessed: 25.06.2019.

Karaer, F. \& Terzioğlu, S. (2014). A new alien record for the flora of Turkey: Sigesbeckia pubescens (Compositae). Turkish Journal of Botany, 37(1), 188-190.

Karyagin, I.I. (Ed.). (1950-1961). Flora of Azerbaijan. Vols. 1-8. Baku, Azerbaijan: Publishing House of Acad. Sci. Azer. SSR.

Keskin, M. (2012). Cerastium L. Güner A., Aslan S., Ekim, T., Vural, M., Babaç, M.T. (Eds.), Türkiye Bitkileri Listesi (Damarle Bitkiler). İstanbul, Turkey: Flora Araştırmaları Derneği.

Keskin, M. (2018). Notes on Cerastium brachypetalum Pers. (Caryophyllaceae) and new subspecies records for Turkish flora. Bağbahçe Bilim Dergisi, 5 (2), 17-24.

Komarov, V.L. (1970). Flora of USSR. Israel Program for Scientific Translations Jerusalem: The Smithsonian Institution, U. S.A. and The National Science Foundation, Washington, D.C.

Miceli, P., Bechi, N. \& Barberis, G. (1997). Biosystematic investigation on perennial Cerastium L. (Caryophyllaceae) populations from Tuscany (NW Italy). Lagascalia, 19(12), 819-830.
Móschl, W. (1966). De Cerastiis florae Iranicae. vorarbeiten zur flora Iranica. 24 Sitzungber. Oesterr. Akad. Wiss. Math. - Natw. Abt. 1, 175(7/8), 159- 217.

Poursakhi, K., Assadi, M., Ghahremaninejad, F., Nejadsattari, T. \& Mehregan, I. (2013). A new subspecies of the genus Cerastium L. (Caryophyllaceae) from Iran. Iran Journal of Botany, 19(1), 47-53.

Rabeler, R.K. \& Hartman, R.L. (2005). Caryophyllaceae. Flora of North America, North of Mexico, New York: Oxford University Press, 5, 3-8.

Scheen, A.C., Brochmann, C., Brysting, A.K., Elven, R., Morris, A., Soltis, D.E., Soltis, P.S. \& Albert, V.A. (2004). Northern hemisphere biogeography of Cerastium (Caryophyllaceae) insights from phylogenetic analysis of noncoding plastid nucleotide sequences. American Journal of Botany, 91, 943-952.

Sell, P.D. \& Whitehead, F.H. (1993). Cerastium L. Tutin, T.G., et al. (Eds.). Flora Europaea .Cambridge: Cambridge University Press, 1 (second ed.), 164-175.

Sokolova, I. (1996). Conspectum generis Cerastium L. (Caryophyllaceae) florae Caucasi. Novosti Sysytematiki Vysshikh Rasteniy, 30, 33-47.

Takhtajan, A. L. (Ed.). (1954-2001). Flora of Armenii. Yerevan: Armenian Academy of Sciences Press, 1, 11.

Terzioğlu, S. \& Anşin, R. (2001). A chorogical study on the taxa naturalized in the eastern Black sea region. Turkish Journal of Agriculture and Forestry, 25, 305-309.

Terzioğlu, S. \& Karaer, F. (2014). An alien species new to the flora of Turkey: Lysimachia japonica Thunb. (Primulaceae). Turkish Journal of Botany, 33(2), 123-126.

Tolmachev, A.I. (1970). Cerastium L. Komarov, V.L., (Ed.). Flora of the USSR. Israel Program for Scientific Translations. Jerusalem (Translated from Russian). The Smithsonian Institution, U. S.A. and The National Science Foundation, Washington, D.C., 6, 330-358. 